Article

\title{
Gender and Public Pensions in China: Do Pensions Reduce the Gender Gap in Compensation?
}

\author{
Tianhong Chen ${ }^{1, *}$ and John A. Turner ${ }^{2}$ \\ 1 Centre for Social Security Studies, Wuhan University, Wuhan 430072, China \\ 2 Pension Policy Center, Washington, DC 20016, USA; E-Mail: jturner@pensionpolicycenter.org \\ * Author to whom correspondence should be addressed; E-Mail: chentianhong@whu.edu.cn; \\ Tel.: +86-133-8763-4768.
}

Academic Editor: Helmut Haberl

Received: 30 October 2014 / Accepted: 14 January 2015 / Published: 27 January 2015

\begin{abstract}
This paper analyzes gender issues with respect to public pensions in China. Because provision of public pensions in China is highly fragmented, with different programs applying to different groups of people, we focus on the largest mandatory public pension program in urban China, the Urban Employees' Pension Program. The paper uses data from the China Health and Retirement Longitudinal Study (CHARLS) for 2011 to empirically analyze the causes of gender differences in benefit levels between men and women. We argue that raising the retirement age for women from its current age for most women of 50 would be a major step toward gender equality in public pension benefits. Women would have higher benefits than currently due to having longer working careers, and they may have higher wages as a result of their longer careers. They would also have higher benefits from the individual accounts pensions due to more years of contributions and investment earnings, and a more generous benefit conversion factor due to the older age when they started receiving benefits. Nonetheless, an important feature of the Chinese public pension system is that the gender gap in benefits is less than the gender gap in earnings. In many countries, the reverse is the situation, in part because women have fewer years of work, as well as lower earnings, than men. We explore reasons why the gender pension gap in China reduces the gender gap in compensation.
\end{abstract}

Keywords: public pension program; old-age benefit; gender; pension gap; China 


\section{Introduction}

Gender differences in retirement benefits arise in China, as in many other countries, with women receiving lower benefits than men. In the European Union, the European Union Directorate-General for Justice has funded research on the gender gap in pensions [1]. That study notes that retirement benefits may amplify the gender pay gap, in part due to a gender gap in years of work. Alternatively, as a matter of social policy, retirement benefits may be structured so as to reduce the gender gap.

In this paper, we use data from 2011 China Health and Retirement Longitudinal Study (CHARLS) to empirically analyze gender differences in retirement benefits and how that is affected by retirement age [2]. The difference in retirement ages between men and women, which is due to government regulations, plays a major role in gender differences in benefits. This paper addresses the question of what reforms are needed in China's retirement income system to provide better retirement income for women, given that their needs differ from those of men due to their longer longevity, and given that their labor market experience differs due to their earlier mandatory retirement ages.

The public pension benefits system is an important mechanism to cope with the risk of having low income in old age. This paper analyzes how well this system works for women in China. It examines whether aspects of the determination of public pension benefits cause the gender pension gap to be greater or less than the gender earnings gap.

This paper is structured as follows. First, the paper provides a review of the literature in China and other countries concerning the gender pension benefit gap. Second, the paper provides background on the labor market experience and demographic characteristics of women compared to men in China. Third, the paper introduces the Urban Employees' Pension Program and focuses on issues that particularly affect women, considering the level of benefit and the lack of spousal and survivor benefits. Fourth, it empirically analyzes retirement age of males and females, the gender earnings gap and the gender pension benefits gap by using the latest data from the 2011 China Health and Retirement Longitudinal Study (CHARLS). Fifth, it offers policy discussion and concluding comments.

\section{Literature Review}

The average gender gap in pensions in the 27 countries of the European Union, weighted by population, is 39 percent, compared to a pay gap of 16 percent [1]. However, here the pay gap refers to pay per hour rather than earnings per year, where the earnings gap would be wider due to differences between men and women in hours worked per year. That study does not include the gender earnings gap. It should be noted that the pay gap is for current workers and the pension gap is for current retirees. The aggregate result for the European Union does not represent the experience in every country. In some countries of the EU, the gender pension gap is less than the gender pay gap.

In Eastern Europe, gender issues in public pensions have been studied by the International Labor Organisation [3]. The Eastern European and former Communist countries of Latvia, Hungary, Lithuania, the Czech Republic, the Slovak Republic and Estonia all have a gender pension gap that is less than half the EU average. Gender differences in pension benefits have also been analyzed in the United States [4,5], where the gender pension gap is greater than the gender earnings gap. Dahl et al. (2003) analyze the gender pension gap in Norway [6]. 
Research about the gender pension gap in China [7,8] points out that monthly salary, contribution years and retirement age are three key factors that influence the benefit level of retired females, as females tend to have lower salary, less contribution years and early retirement age. Drew (2011), in the context of a broader study of benefits, provides some data comparing male and female retirees in China [9]. Pei (2011) concludes that the previous literature on gender pension gap is "rather limited", and this is explained in part by the lack of data [10]. Pei (2011) uses data for 1999 and 2008 for five cities or municipalities to examine causes of the difference in pension benefit levels between men and women in urban areas in China. Those causes include retirement age, earnings and education. He finds that the gender gap for pensions was slightly larger than for wages in 1999 but finds mixed results for 2008 , with it being slightly larger for older retirees but slightly smaller for younger retirees [10]. When he applies these results to the entire urban population for 2011 using an actuarial model, he finds that the gender gap for pensions is less than for wages [10].

The problem of retirement income for women is worsened by an early retirement age of 50 for most Chinese women, compared to 60 for men. Compared with other countries, China has the largest gap between public pension retirement ages for men and women [10].

\section{Background}

Several factors motivate this analysis of gender pension issues in China. China has the largest population and largest old-age population in the world. From 1990 to 2012, the total population in China increased from 1143.3 million to 1354.0 million, and the ratio of the population aged 65 and older to the total population increased from 5.6 percent to 9.4 percent [11]. According to demographic projections, by 2030 the population aged 65 and older will be 16.2 percent of the total population and by 2040 it will increase to 22.2 percent [12]. Moreover, data from the 2010 China Population Census indicates that the total number of widowed people is around 60 million, among which 79.1 percent are aged 60 and older and about 33 million are female widows [13]. Gender issues arise in retirement income systems as women tend to have different economic and demographic characteristics than men. Comparison of economic and demographic characteristics of males and females provides a background to analyze the gender pension gap in China. As discussed below, women tend to have lower wages and shorter work histories than men, which result in them having lower pension benefits. They have longer life expectancy than men, and tend to outlive their spouses, which result in them having a greater need for retirement benefits and which make the lack of provision of survivor benefits in China more important for them.

\subsection{Sources of Income in Old Age for Males and Females}

In China, public pension entitlements are provided on an individual worker basis, with no spouse benefits and generally no survivor benefits. Thus, women in China are particularly vulnerable in old age as widows. According to data of the 2010 China Population Census, labor income, retirement benefits and support from family are the main sources of income for males and females aged 60 and older (Table 1).

Nevertheless, differences exist in the relative importance of the sources of support for males and females. Fewer females receive labor income (21.9 percent) and retirement benefits (19.6 percent), 
compared to males (36.6 percent and 28.9 percent, respectively) (Table 1). A key statistic is that 52.6 percent of females aged 60 and older depend on family support, compared to only 28.2 percent of males (Table 1). Thus, older females are nearly twice as likely as older males to depend on family support, indicating the importance of improving public pension benefits for older women. In particular, divorced and widowed females depend heavily on family support (37.2 percent and 66.1 percent, respectively) (Table 1).

Table 1. Main sources of income for people aged 60 or older in China, by gender and marital status (percent) [13].

\begin{tabular}{ccccccc}
\hline & $\begin{array}{c}\text { Labor } \\
\text { income }\end{array}$ & $\begin{array}{c}\text { Retirement } \\
\text { benefit }\end{array}$ & $\begin{array}{c}\text { Support } \\
\text { from family } \\
\text { Male }\end{array}$ & $\begin{array}{c}\text { Minimum } \\
\text { guarantee }\end{array}$ & $\begin{array}{c}\text { Asset } \\
\text { income }\end{array}$ & Others \\
\hline In total & 36.6 & 28.9 & 28.2 & 4.1 & 0.4 & 1.8 \\
Single & 38.2 & 4.1 & 14.2 & 36.4 & 0.3 & 6.8 \\
Married with spouse & 39.4 & 31.7 & 24.5 & 2.4 & 0.5 & 1.5 \\
Divorced & 34.8 & 30.7 & 21.1 & 10.0 & 0.5 & 2.8 \\
Widowed & 22.7 & 19.9 & 49.8 & 5.4 & 0.3 & 2.0 \\
\hline & \multicolumn{7}{c}{ Female } & & & \\
\hline In total & 21.9 & 19.6 & 52.6 & 3.7 & 0.3 & 1.9 \\
Single & 16.6 & 15.7 & 45.8 & 14.3 & 0.3 & 7.3 \\
Married with spouse & 28.6 & 22.0 & 44.7 & 2.5 & 0.4 & 1.8 \\
Divorced & 14.3 & 40.5 & 37.2 & 5.1 & 0.5 & 2.4 \\
Widowed & 10.9 & 15.1 & 66.1 & 5.5 & 0.3 & 2.1 \\
\hline
\end{tabular}

\subsection{Labor Market Participation of Males and Females}

In 1988, the employment rate (employment relative to population) for persons with urban registration ages 16 to 64 was 83 percent for men and 75 percent for women. However, economic reform has encouraged labor mobility and allowed workers to choose where and whether they would be employed. By 2002, the employment rate had fallen to 75 percent for men and 59 percent for women. By 2009, the rate was unchanged for men but had fallen slightly more for women to 57 percent [14].

Part of the explanation for the decline in employment is that a decline in employment has occurred for older workers. For men, the decline occurred in their fifties, while for women it occurred in their forties. The employment ratio for men age 55 to 65 fell from 62 percent in 1988 to 48 percent in 2009 . The employment ratio for women age 45 to 65 fell from 53 percent in 1988 to 39 percent in 2009 . Studies have documented that these changes were due largely to older workers losing their jobs because of economic restructuring and being unable to find work, so they became discouraged and left the labor force [14].

Females not only have a lower labor force participation rate, they also tend to have lower earnings than males. From 1990 to 2010, the income gap between men and women widened, according to three national surveys. The annual income of female workers in urban area was about 78 percent of that of their male counterparts in 1990. The ratio dropped to 70 percent in 1999 and 67 percent in 2010 [15]. 


\subsection{Life Expectancy of Males and Females}

In China, life expectancy has improved dramatically. For the period 1950 to 1955 , life expectancy at birth for males and females was 39.3 and 42.3 years, respectively. In the period from 2010 to 2015, life expectancy for males is 74.0 and for females is 76.6. The longer life expectancy of females points out the importance of public pension for them, especially when females outlive their male spouses.

\section{Effects of Institutional Features of the Public Pension Program on the Pension Benefits of Males and Females}

China has three main public pension old-age benefits programs, covering three different groups of people. Urban areas have two old-age benefits programs - the Urban Employees' Pension Program and the Urban Residents' Pension Program. The Urban Employees' Pension Program covers employed workers with rural or urban registration in urban areas. The Urban Residents' Pension Program, started in 2011, is a voluntary program for people with urban registration who do not have a job. The National Rural Pension Scheme is a voluntary program for most people with rural registration. Smaller programs cover government workers, rural migrants to urban areas, and farmers who have had their land appropriated by the government.

The Urban Employees' Pension Program was established in 1997. The urban labor force in China is larger than the total labor force in any other country except India [10]. By the end of 2012, 303.8 million employees participated in this program, of which there were 229.8 million contributors and 74.0 million beneficiaries [11]. In this paper, we focus on the Urban Employees' Pension Program and analyze different effects on the benefits of females and males.

\subsection{Contributions}

The contribution rate for this program is 28 percent of wages, of which the employee contributes 8 percent to an individual account. The 20 percent rate the employer contributes to the social account for the basic pension is a standard suggested by the central government. The exact contribution rate for the social account can be decided by local government, and can be higher or lower. The 8 percent rate paid by the employee for the individual account is the same rate across China. This account is linked to the individual participant and is not affected by the age structure in the region.

\subsection{Retirement Age for Public Pension Benefit Receipt}

The retirement age for public pension benefit receipt is 60 for men. It is 60 for women working in certain professions, 55 for female managers, and 50 for other women, with most women having a retirement age of 50. Though retirement age is mandatory for most people, exceptions exist, including for some university professors. Retirement age is reduced for those working in hazardous occupations or who are seriously ill or disabled because of work. For those who have worked in hazardous occupation for a certain number of years and contributed to the public pension program for at least 15 years, the public pension benefit ages for males and females are 55 and 45 . However, males can apply for public pension benefits at age 50 and females can do this at age 45 , on the condition that they have contributed for at least 15 years. 
As no specified and clear standard of hazardous occupations and disability are given, employers tend to help employees to apply for public pension benefits earlier to reduce their cost for older employees. Early retirement is quite common for both women and men [16]. A study in 2006 reveals that among 17.6 million retirees, 10.0 million (56.8 percent) retired earlier than their normal retirement age [17]. One study found an average retirement age in urban areas of 53 [18].

\subsection{Benefits}

The retirement benefit consists of two parts - a basic benefit from the social account pension and an individual account benefit. According to statistics of the Ministry of Human Resources and Social Security, the average benefit level of the Urban Employees' Pension Program at the end of 2011 was 1721 yuan per month [19]. These statistics, and the data set we use later in this paper, do not separate out the social account pension benefits and the individual account benefits.

\subsection{Gender Pension Gap Caused by Program Regulations}

In this section, we analyze causes of the gender pension gap by analyzing the historical development of pension benefit regulations. In a subsequent section, we analyze how the different labor market experiences of men and women interact with the pension benefit regulations to produce gender differences in benefits.

Analysis of the gender pension gap for current retirees in China is complicated by the changes that have occurred over time in the way that retirement benefits have been calculated. The gender pension benefits gap among retirees currently in China is related to the historical development of the urban public pension program. The benefits calculation differs for three cohorts of retirees: those retired before 1997, those retired between 1997 and 2005, and those retired after 2005.

Before 1997, retired workers received retirement benefits from their employers, with high replacement rates of 60 percent for 10 years of work, 70 percent for 15 years, and 75 percent for 20 or more years [18]. In 1997, the Urban Employees' Pension Program was first established in China, which is composed of a social account and an individual account. The contribution rates to the social account and individual account were adjusted several times and finally set at the current rates of 20 percent and 8 percent, respectively.

For workers who started to work before 1997 but retired between 1997 and 2005, the social account part of the Urban Employees' Pension Program provided the same benefits for all retirees, regardless of number of years worked, the level of the worker's earnings or the age at which the worker retired. During this period, the retirement benefits from the social account were calculated as 20 percent of the average wage for their area for the year prior to the employee's retirement age. Personal contributions only affected the total amount in the individual account, which was divided by 120 to calculate individual account benefit, with the same divisor regardless of the age at which the person retired. In addition, during this period, a transitional benefit was paid for work before 1997. The transitional benefit takes into account years of work before 1997 and the worker's earnings. For workers who started to work before 1997 but retired after 2005, their benefits are calculated according to the new system, explained in the next paragraph. 
For those who started work after 1997, contribution level, contribution years and retirement age are taken into account to calculate retirement benefits. The basic benefit from the social account pension is calculated by multiplying the following two elements. The first element is a percentage determined by total contribution years, where one contribution year equals 1 percent. For instance, if a male worker contributed 35 years, he has a 35 percent coefficient in this part. The second element is a number obtained by adding the average wage of the year prior to the employee's retirement age with the average indexed monthly wage of the employee and then dividing by two. The average wage used in this calculation is the average wage for the pooling area where the worker resides at the time of retirement. The average indexed monthly wage of the employee is adjusted for wage increases for every year before the person retires, and is thus wage indexed.

This benefit formula for workers who started work after 1997 can be analyzed for its effects on women $v s$. men. The first and second parts of the benefit calculation have different effects on women. Women receive lower benefits than men because they have fewer years of contributions, in part due to their lower retirement age (the first part of the calculation). However, the calculation of wages for determining benefits is advantageous to women relative to men because the use of the average wage for the region raises their benefits, while it lowers the benefits of men (the second part of the calculation). Women gain in the calculation of the average because men's average wages are higher and because there are more men than women in the workforce, which also raises the average wage for the workforce relative to average wages for women.

Despite the boost that women receive in benefits from the averaging of wages with men, when both their years of work and their wages used for calculating benefits are lower than men's, the benefit formula will tend to worsen the gender gap, or at least not improve it, because it is a multiplicative formula. For example, if their years of work were 80 percent those of men and the average wage used for calculating benefits was 90 percent that of men, the multiplication of those two factors would result in benefits that were 72 percent those of men, which is approximately the earnings gap. Retirees also receive a benefit based on the amount credited to their individual account from their contributions and accrued investment returns. The monthly benefit based on the individual account is the credited balance in the worker's individual account balance at the time of retirement divided by 139, for both males and females retiring at age 60 (Table 2). The divisor depends on the age at which the person collects benefits, but not on gender, with it being higher at lower ages. It is 195 for those retiring at age 50 and 170 for those retiring at age 55 in the urban pension system (Table 2). Thus, women's benefits are reduced by having a lower retirement age than men and fewer years to contribute to the individual account. The benefits for women are further reduced by having a higher divisor when calculating benefits from their individual account because of their younger age at retirement.

Table 2. Retirement age, divisor of individual account for determining an annuity, and life expectancy after retirement [20].

\begin{tabular}{cccc}
\hline \multirow{2}{*}{ Retirement age } & \multirow{2}{*}{ Divisor of individual account } & \multicolumn{2}{c}{ Life expectancy after retirement (months) } \\
\cline { 3 - 4 } & 195 & 380.4 & Female \\
\hline 50 & 170 & 325.2 & 416.1 \\
55 & 139 & 272.4 & 360.0 \\
60 & 101 & 223.2 & 304.8 \\
65 & & 253.2 \\
\hline
\end{tabular}


The individual account pension thus can also be analyzed for its effect on the benefits of women $v s$. men. The larger divisor for women than men in determining benefits from the mandatory individual account system is one of the factors causing women to have lower benefits than men. If women retired at age 60 instead of age 50, their benefits from the individual account system would be 40 percent larger, not taking into account the increase due to the added years of contributions and investment earnings, which would cause a further increase in their benefits.

Data are not available on the size of the benefits from the individual account pension. The contributions to these accounts of 8 percent are 29 percent of the total public pension contributions, when the total contribution rate is 28 percent. However, because these accounts are credited the low rates of return on bank accounts, the benefits from them are probably less than 29 percent of total benefits on average. They would be a smaller percentage of benefits for women than for men because the social benefit is more generous for women than men due to the use of the social average wage in the benefit computation, as explained above.

The benefit payment is not limited to the amount in the individual account, but is guaranteed by the government for life, and thus is paid as a life annuity. As shown in Table 2, expected months of living for those who retire at age 50 are 416.4 months and 380.4 months for females and males, respectively. As is typical for public pension programs, the divisor for determining benefits is the same for men and women, thus providing greater lifetime benefits for women than men, because of their longer lifetimes, but equal annual benefits for a given account balance. If the person dies before receiving the full amount in their individual account, the spouse receives the remaining amount, then the children, if the spouse is not surviving. The system does not provide a benefit to a surviving spouse if the amount credited to the account has been paid in benefits. This arrangement is disadvantageous to women because they are more likely than men to be the survivor in a marriage.

\section{Empirical Analysis of Retirement Benefits of Males and Females}

Women in China, like in other countries, have lower public pension benefits than men. In this section, we analyze data from the 2011 China Health and Retirement Longitudinal Study (CHARLS) to compare retirement benefits of female and male retirees [2]. The 2011 CHARLS is a national survey targeting those aged 45 and older in China. The sampling protocol is that one member of the household age 45 and over is sampled and their spouse (no matter what age) is automatically included. This survey covered 150 counties and districts, 10,257 households and 17,708 individuals. In this paper, we use data about those who have applied for retirement benefits from the Urban Employees' Pension Program at the time of the survey.

\subsection{Summary Statistics for Male and Female Retirees in 2011 CHARLS}

In total, in our data 2077 individuals were retirement beneficiaries in the Urban Employees' Pension Program in 2011 CHARLS, among which 1039 were males and 938 were females (Table 3). In age distribution, 1.5 percent of males were under age 50 and 81.5 percent of males were aged 60 and older. About 5.6 percent of female respondents were under age 50 when they were surveyed in 2011 and about half of them (49.2 percent) were above age 60 . Besides, 6.6 percent and 3.3 percent of males and 
females were aged above 80. Table 3 also shows that women are more than twice as likely as men (19.3 percent vs. 7.2 percent) to be single, divorced or widowed in this survey.

Table 3. Basic demographic information for male and female retirees in China [2].

\begin{tabular}{cccccc}
\hline \multirow{2}{*}{ Variables } & \multicolumn{2}{c}{ Male } & \multicolumn{2}{c}{ Female } \\
\cline { 2 - 6 } & \multirow{2}{*}{ Gender distribution } & Frequency & Percent & Frequency & Percent \\
\hline \multirow{4}{*}{ Age distribution } & Under 50 & 1039 & 54.8 & 938 & 45.2 \\
& $50-55$ & 17 & 1.5 & 52 & 5.5 \\
& $55-60$ & 159 & 3.1 & 187 & 19.9 \\
& $60-80$ & 853 & 74.9 & 237 & 25.3 \\
\multirow{2}{*}{ Health status } & Above age 80 & 75 & 6.6 & 31 & 46.0 \\
& Fair or poor & 392 & 40.5 & 259 & 3.3 \\
\hline \multirow{2}{*}{ Marital status } & Good & 577 & 59.6 & 534 & 67.3 \\
\hline & Single, divorced or widowed & 82 & 7.2 & 181 & 19.3 \\
& Married and having spouse & 1057 & 92.8 & 757 & 80.7 \\
\hline
\end{tabular}

\subsection{Calculation of the Gender Pensions Gap and the Gender Earnings Gap and Comparison of} Retirement Ages for Males and Females

In this section, average current monthly benefits, average pre-retirement salary, average eligible years of work for benefits and average retirement age in our sample from the 2011 CHARLS are compared for males and females. The average current monthly retirement benefits of male and female retirees are 1883 yuan and 1495 yuan per month, respectively. Thus, current retirement benefits of females are 79.4 percent that of males, a gender pension gap of 20.6 percent. Distribution of retirement benefits is illustrated in Figure 1. About 78.7 percent of males receive public pension benefits of 1000 to 3000 yuan per month, and the corresponding percentage for females is 72.8 percent. More males (8.7 percent) receive benefits higher than 3000 yuan per month while more females (23.0 percent) receive benefits lower than 1000 yuan per month, when males and females are compared.

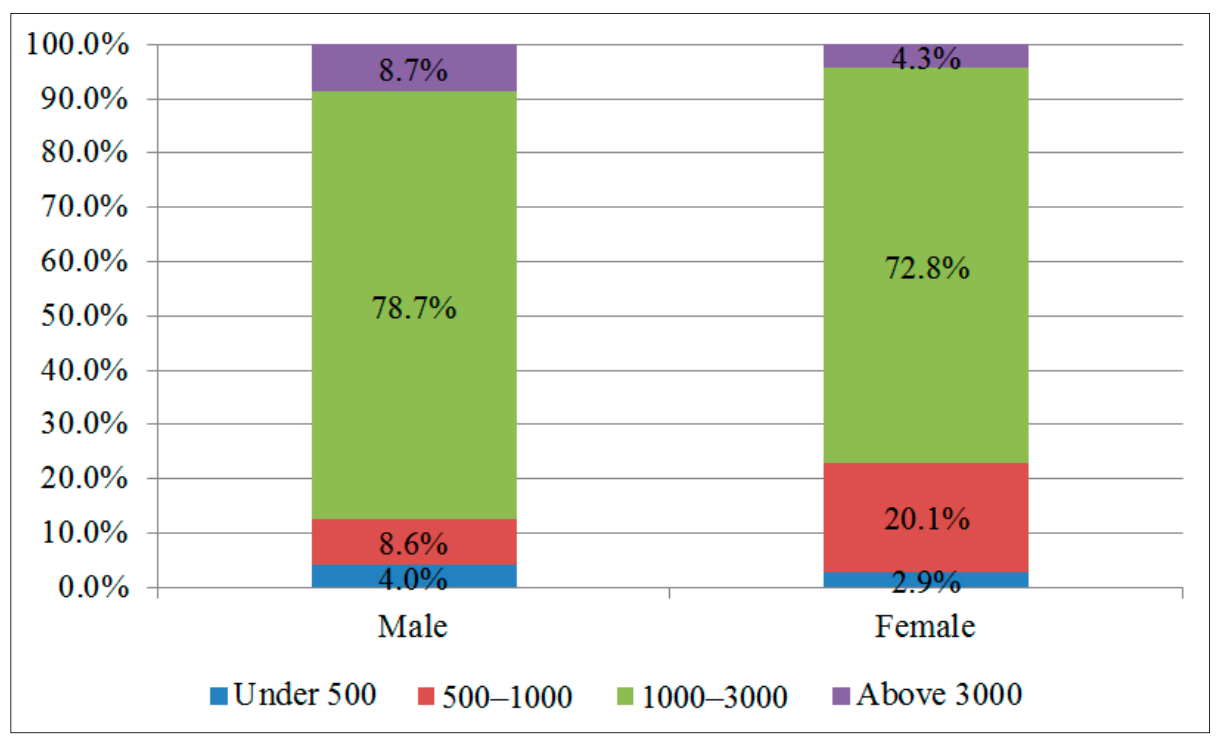

Figure 1. Distribution of average current monthly pension benefits, by gender [2]. 
Average pre-retirement monthly salary levels are 1135 yuan and 828 yuan (both are in 2011 yuan), respectively, for female and male workers. Thus, women have pre-retirement salaries that are 73.0 percent that of men (a gap of 27.0 percent), but their current retirement benefits are 79.4 percent that of men (a gap of 20.6 percent).

Females not only earn less per month than males in China, they also have fewer eligible years of work for retirement benefits than male retirees. Average eligible years of work of female retirees is 27.8 years, which is 78.7 percent that of male retirees (35.3 years) (Figure 2). For females, 43.0 percent have eligible years of 20 to 30 years (Figure 2). By contrast, 75.4 percent of male retirees have more than 30 years of eligible years. As eligible years of work are counted in calculating retirement benefits, female retirees receive lower benefits than male retirees because they have fewer eligible years of work.

Women in the Urban Employees' Pension system have fewer years of work than men because they face retirement at age 50. The average retirement age for women is 50.9 years, compared to the average for men of 57.2, a difference of 6.3 years. The difference between women and men in average eligible years of work is 7.5 years. Thus, most of the difference in years of work occurs because women retire earlier than men, rather than being due to women taking time out from working. Women in China take less time out from working for child rearing than in other countries because of the one child policy.

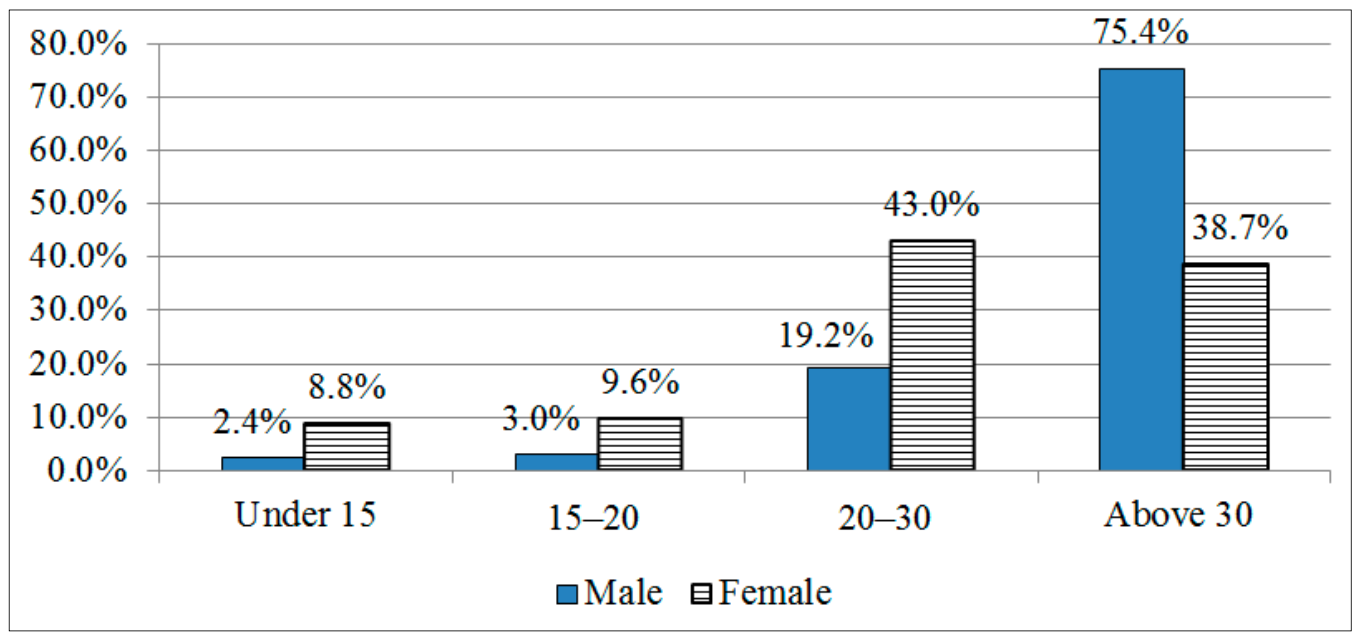

Figure 2. Distribution of eligible years of work for retirement benefits, by gender [2]. Note: According to retirement regulation, workers have to contribute for at least 15 years to apply for public pension benefits. Those who have less than 15 eligible years of work can make a lump sum contribution payment.

The effect of the difference in retirement ages on years of work points out the importance of the earlier retirement ages for women. If women retired at the same ages as men, their retirement benefits would be substantially higher than they are currently. Instead of women's average years of work at retirement being 78.7 percent of men's, the years of work would be 96.6 percent of men's. This change would increase women's retirement benefits by more than 20 percent, not including a possible effect of raising their wages because of their longer careers. 
The distribution of retirement ages of males and females in the 2011 CHARLS is shown in Figure 3. About 52.5 percent of males retired before age 60 and 23.4 percent of females retired before age 50 . Retirements spike at age 60 for men and age 50 for women. About 80 percent of males retired at age 60 or younger and approximate 60 percent of females retired at age 50 or younger. About 28.1 percent male workers in this survey retired at age 60 and 19.4 percent retired after age 60 .

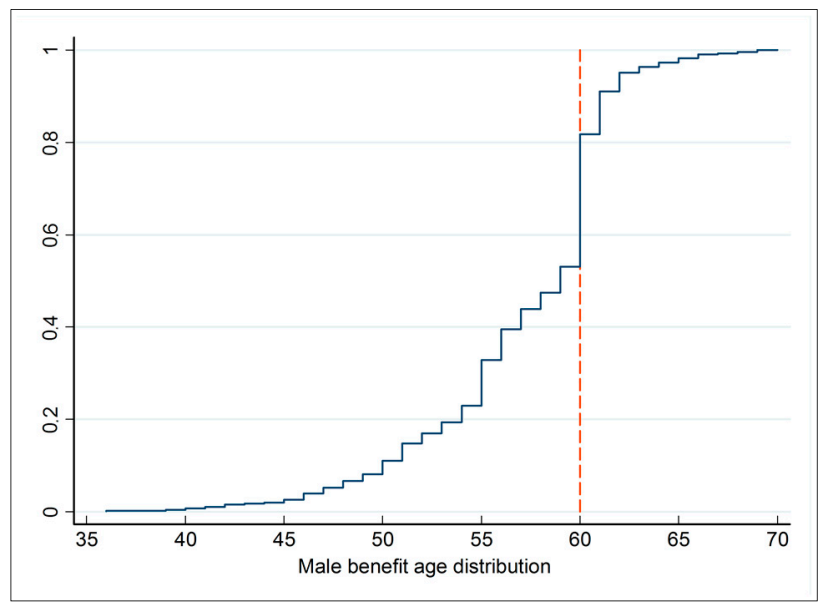

(a)

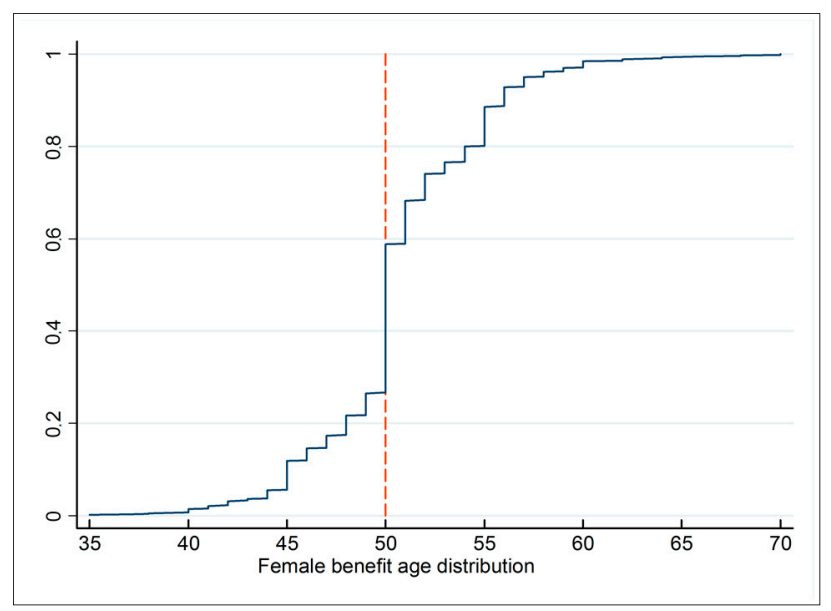

(b)

Figure 3. Cumulative distribution of retirement age, by gender [2].

\subsection{Explanations of the Gender Pension Gap and Its Changes in China}

As discussed above, the gender pension gap is 20.6 percent in the 2011 CHARLS sample, which is considerably smaller than the gender pension gap reported at the start of the paper for the EU, which is 39 percent, and is smaller than the gender earnings gap in China, which is 27.0 percent. Thus, these statistics indicate that the public pension benefits from the Urban Employees' Pension system reduce the gender gap in compensation (earnings plus pensions) relative to the gender gap in earnings, and that the gender pension gap in China is considerably less than in the European Union.

This result that the pension system reduces the gender gap in income is a major feature of the retirement income system in China. Understanding why this occurs may provide important lessons for other countries. Part of the explanation is that the calculation of benefits in the Urban Employees' Pension system from 1997 to 2005 was highly egalitarian, with only the relatively small individual account causing differences by gender. After 2005, contribution level, contribution years and retirement age are considered to calculate retirement benefits. That leaves the question as to whether the Urban Employees' pension system after 2005 still has the effect of reducing the pension gender gap.

To empirically analyze the effect of social account and individual account composition and the method to calculate retirement benefits on the gender pension gap, we calculate the gender earnings gap and the gender pension gap of three cohorts of retirees: those retired at 1997 and before, those retired between year 1997 and 2005, and those retired after 2005 (Table 4). For the first cohort, the average pre-retirement salary of females is 73.7 percent of that of males, while the average current monthly benefits of females is 79.6 percent of that of males. For the cohort retired between year 1997 and 2005, the ratios of pre-retirement salary and retirement benefit of females and males are 74.3 percent and 82.3 percent, respectively. As we discussed above, between the years 1997 and 2005, 
the retirement benefit from the social account was 20 percent of the social average wage and the individual account benefit was calculated with a divisor of 120 for all retirees, regardless of age at retirement. During this period, the gender pension gap (17.7 percent) is smaller than the gender pay gap (25.8 percent). For the cohort retired after year 2005, the gender pension gap (25.4 percent) is almost the same as gender pay gap (25.6 percent) and is larger than the gender pension gap of the former two cohorts (20.4 percent and 17.7 percent, respectively). Thus, the gender pension gap may increase in the future as the older cohorts of retirees are replaced by younger cohorts.

Table 4. Gender pre-retirement salary and retirement benefit gap, by retirement period (yuan per month; \%) [2].

\begin{tabular}{|c|c|c|c|c|c|c|c|c|}
\hline & \multicolumn{4}{|c|}{ Average pre-retirement salary } & \multicolumn{4}{|c|}{ Average current monthly benefits } \\
\hline & $\begin{array}{c}\text { Female } \\
\text { (1) }\end{array}$ & $\begin{array}{c}\text { Male } \\
(2) \\
\end{array}$ & $(1) /(2)$ & $\begin{array}{c}\text { Gender } \\
\text { Gap }\end{array}$ & $\begin{array}{c}\text { Female } \\
(5)\end{array}$ & $\begin{array}{c}\text { Male } \\
(6)\end{array}$ & $(5) /(6)$ & $\begin{array}{c}\text { Gender } \\
\text { Gap }\end{array}$ \\
\hline 1997 and before & 595.8 & 808.5 & 73.7 & 26.3 & 1553.8 & 1951.4 & 79.6 & 20.4 \\
\hline 1997-2005 & 876.2 & 1180.1 & 74.3 & 25.8 & 1527.5 & 1855.3 & 82.3 & 17.7 \\
\hline After 2005 & 1091.9 & 1468.1 & 74.4 & 25.6 & 1387.0 & 1858.9 & 74.6 & 25.4 \\
\hline
\end{tabular}

The smaller gender pension gap than gender wage gap may be partially explained by the retirement benefits adjustment process in China. Yang \& Shen (2012) find that though retirement benefits in payment have been adjusted almost every year since 1997, no unified and clear rule about how to adjust the benefit level for inflation is given, and the adjustment mechanism is decided by the local public pension departments [20]. In 1997, the percent of retirement benefits increase was required to be 40 percent to 60 percent of the social average wage increase index. In 1999, retirement benefits were increased by 15 percent of social average retirement benefits, which means that all retirees received the same percentage amount of benefit increase. In 2001, the percent of retirement benefits increase was required to be 60 percent of social average wage increase index, while in 2002, it decreased to 50 percent of the social average wage increase index. From 2008 to 2013, retirement benefits were increased each year by 10 percent of each retiree's retirement benefits. The 10 percent increase of retirement benefits is higher than the CPI index. Wang \& Zeng (2004) pointed out that as the increase index of retirement benefits is higher in recent years than that of the average wage increase, the public pension program provides early retirement incentive to older workers [21]. It, however, may be a factor causing the pension gender gap to be less than the wage gender gap because women on average benefit from seven years of adjustments greater than wage increases before men reach their retirement age.

\section{Policy Discussion}

Because of economies of scale in household consumption, living expenses are less per person, in particular housing expenses, when there are two people (a married couple) in the household than when there is one person. When a woman's husband dies, her income would need to be more than 50 percent of their joint income in order to maintain her standard of living, but generally it falls to less than 50 percent of their joint income. It falls to less than 50 percent of their joint income because her husband's benefits, which are generally higher than hers, are no longer being received. For men, 
the situation is reversed. This situation for women may explain the continuing prevalence of older widows living with their adult children.

In China, a temporary survivor benefit is received by women if the husband dies before having received the full amount of his individual account benefits. The survivor benefit is the remaining amount in the individual account. Otherwise, no survivor benefit is received. While both are alive, each person receives their own public pension benefits based on their own earnings and contributions record. There are no spouse benefits.

Two approaches could be taken for improving the retirement benefits of women. The first approach would be to provide survivor benefits as part of the Urban Employees' Pension Program. The second approach would be to improve the retirement benefits that women earn for themselves. That approach would appear to be more consistent with the current structure of retirement benefits in China. A single change that would have a substantial effect would be to raise the retirement age for women to that of men. This change would be consistent with public pension programs in many other countries. If it were done, it would be desirable to do it in such a way as to limit the disruption to women who are currently working. Thus, it would be desirable to have a lead time before the change started, such as ten years, then phase in the change over time. However, if it were phased in at the rate of four months per year, the phase in would take 30 years. Thus, a faster phase-in would be needed. For that reason, a phase in of six months per year might be considered.

\section{Conclusions}

This paper examines gender issues in retirement income security in China. We find that the gender pension gap in China is considerably less than in the European Union. Further, the gender pension gap in China is less than the gender earnings gap, which is the reverse of what is found in the EU. Examining different cohorts of retirees, we find that the gender pension gap is higher for those who retired after 2005 than for those who retired earlier. Thus, the gender pension gap may increase in the future as the older cohorts of retirees are replaced by younger cohorts.

We analyze both the structure of the public pension benefits and data on the labor market experience and benefits of beneficiaries. Analysis of the structure of the benefits programs indicates that at the beginning of retirement, the retirement age of 50 for most Chinese women results in low benefits due to a relatively short working life. At the end phase of life, Chinese women are more likely than men to be single, divorced, or widowed, and for those who were married, they are likely to not be receiving survivor benefits.

The early retirement age of 50 for women disadvantages women in terms of the level of retirement benefits they receive. Data from the CHARLS data set indicate that it accounts for most of the difference between men and women in number of years worked at retirement. For that reason, we recommend a policy of gradually raising the retirement age of women so that it eventually will equal that of men. This change would be an important step toward the equal treatment of men and women in the Chinese labor market. 


\section{Acknowledgments}

We thank two reviewers for helpful comments. We acknowledge the support of the Fundamental Research Funds for the Central Universities (2013115010201) and the research project Social Security Actuarial Research (11JJD840017) in China.

\section{Author Contributions}

John Turner designed the research project. Tianhong Chen and John Turner discussed the structure and finished writing this article. Both authors read and approved the final draft of the article.

\section{Conflicts of Interest}

The authors declare no conflict of interest.

\section{References}

1. Bettio, F.; Tinios, P.; Betti, G. The Gender Gap in Pensions in the EU. Available online: http://ec.europa.eu/justice/gender-equality/files/documents/130530_pensions_en.pdf (accessed on 18 June 2014).

2. China Health and Retirement Longitudinal Study (CHARLS) 2011. Available online: http://charls.ccer.edu.cn (accessed on 18 January 2014).

3. Fultz, E.; Ruck, M.; Steinhilber, S. The Gender Dimensions of Social Security Reform in Central and Eastern Europe: Case Studies of the Czech Republic, Hungary and Poland; International Labor Office Subregional Office for Central and Eastern Europe: Budapest, Hungary, 2003.

4. Even, W.E.; Turner, J.A. Has the Pension Coverage of Women Improved? Benefits Q. 1999, 15, 37-40.

5. Even, W.E.; Macpherson, D.A. When will the Gender Gap in Retirement Income Narrow? South. Econ. J. 2004, 71, 182-200.

6. Dahl, S.A.; Nilsen, O.A.; Vaage, K. Gender Differences in Early Retirement Behaviour. Eur. Sociol. Rev. 2003, 19, 179-198.

7. Wu, K. Gender Difference Should be Considered in Pension Plan. Popul. Econ. 2002, 133, 59-63.

8. Liu, X.H. Analysis on the Change of Benefits by Sex in the Course of the Old-Age Insurance Reform. Popul. Econ. 2010, 182, 58-64.

9. Drew, E. Gender Balance in Social Security Reform China, EU-China Social Security Reform Co-Operation Project. Available online: http://www.academia.edu/997306/Gender_Balance_in_ Social_Security_Reform_China (accessed on 20 June 2014).

10. Pei, D. Gender Difference of Pension Benefits in Urban China. Available online: http://arno.uvt.nl/show.cgi?fid=121849 (accessed on 20 June 2014).

11. National Bureau of Statistics of China. China Statistical Yearbook. Available online: http://www.stats.gov.cn/tjsj/ndsj/2013/indexch.htm (accessed on 12 May 2014).

12. Organisation for Economic Co-operation and Development (OECD). Ageing Societies. In OECD Factbook 2009: Economic, Environmental and Social Statistics; OECD Publishing: Paris, France, 2009. Available online: http://dx.doi.org/10.1787/factbook-2009-3-en (accessed on 12 May 2014). 
13. National Bureau of Statistics of China. China Population Census. Available online: http://www.stats.gov.cn/tjsj/pcsj/rkpc/6rp/indexch.htm (accessed on 12 March 2014).

14. Meng, X. Labor Market Outcomes and Reforms in China. J. Econ. Perspect. 2012, 26, 75-102.

15. China Daily. Gender Income Gap Continues to Widen. Available online: http://www.chinadaily. com.cn/china/2013-05/16/content_16502360.htm (accessed on 12 May 2014).

16. Feng, J.; Hu, Y. An Empirical Study of Early Retirement in Urban China. Chin. J. Popul. Sci. 2008, 4, 88-96.

17. Yang, Y.N. Empirical Research on Influencing Factors of Retirement Age in China. Insur. Stud. 2011, 11, 61-71.

18. Sin, Y. China: Pension Liabilities and Reform Options for Old Age Insurance; Working Paper No. 2005-1; World Bank: Washington, DC, USA, 2005.

19. Ministry of Human Resources and Social Security (China). Annual Human Resources and Social Security Development Statistical Bulletin of 2011. Available online: http://www.mohrss.gov.cn/ SYrlzyhshbzb/zwgk/szrs/ndtjsj/tjgb/201206/t20120605_69908.htm (accessed on 12 May 2014).

20. Yang, Y.N.; Shen, S.G. Inflation and Wage Growth: New Method and Systematic Scheme for the Adjustment of China's Basic Pension System. Insur. Stud. 2012, 8, 95-103.

21. Wang, Z.Y.; Zeng, X.Q. An Analysis of the Relation between Chinese Social Security Benefit Incentives and Enterprise Staff and Workers Retirement Age. J. Renmin Univ. 2004, 6, 74-78.

(C) 2015 by the authors; licensee MDPI, Basel, Switzerland. This article is an open access article distributed under the terms and conditions of the Creative Commons Attribution license (http://creativecommons.org/licenses/by/4.0/). 